\title{
Change in E-learning Readiness and Challenge for Myanmar Higher Education
}

\author{
Mon Mon The, Tsuyoshi Usagawa \\ Department of Computer Science and Electrical Engineering, Graduate School of Science and Technology, Kumamoto University, \\ Kumamoto, Japan \\ Email: monmonthe@gmail.com, tuie@cs.kumamoto-u.ac.jp
}

How to cite this paper: The, M. M., \& Usagawa, T. (2018). Change in E-learning Readiness and Challenge for Myanmar Higher Education. Creative Education, 9, 1277-1286.

https://doi.org/10.4236/ce.2018.99095

Received: April 17, 2018

Accepted: July 3, 2018

Published: July 6, 2018

Copyright (c) 2018 by authors and Scientific Research Publishing Inc. This work is licensed under the Creative Commons Attribution International License (CC BY 4.0).

http://creativecommons.org/licenses/by/4.0/

(c) (i) Open Access

\begin{abstract}
The advantage of technology has paved way for innovation in higher education. Because of being cost-effective, unlimited time and place, the universities from the developing world are also trying to integrate e-learning into their traditional education system. However, as a fundamental process, they require the readiness assessment before their e-learning implementation. Moreover, the evaluation on readiness should be done as on-going process so that readiness movements are able to be confirmed, and necessary preparations in line with their updates can be effectively done. The purpose of this study was to investigate if the e-learning readiness of two Myanmar technological universities are stable or not, and to find out which items happened the highest difference between 2016 and 2017. To examine the changes in e-learning readiness, the paper-based data collection was done using questionnaires and shared toward 648 students in 2016 and 1024 students in 2017. Data analysis was done by indexes of descriptive statistics and independent $t$-test. Findings reveal that their readiness was a significant decline in 2017. Moreover, the items with highest changes were addressed, and the readiness levels on each studied dimension were also measured. In addition, the study points out blackout problems found in Myanmar universities. Understanding the barriers directed by e-learning readiness encourages Myanmar universities to make an e-learning effort on what kind of strategies and preparation should be emphasized.
\end{abstract}

\section{Keywords}

E-Learning Readiness, Students, Change, Readiness Level, Challenge

\section{Introduction}

Nowadays, e-learning as a new paradigm shifts higher-education from instruc- 
tor-centered to learner-centered and it enhances the quality of teaching and learning by integrating ICT and internet technologies. Applying e-learning in the educational environment encourages the universities and schools to facilitate their learners and enhance their learning opportunities. Furthermore, it can compensate the weakness of traditional education methods and enables the instructors to transfer their knowledge for a relatively large number of students without space and time limitation (Aung \& Khaing, 2016). Additionally, as e-learning has the benefits of being low-cost, user friendly, keenly motivating and broadly available, it has started a growing demand from higher education of developing countries while they are facing shortage of expert teachers, shortage of update text books and limited teaching materials. Like other countries, Myanmar realizes that conventional education alone cannot cope with all the demands of higher education, and ICT-based education will play an important role in Myanmar higher education reform (Tint, 2012; Po, 2015; Yin, 2016).

However, the adoption and acceptance of e-learning systems is a vital challenge, especially in developing countries because they have numerous barriers such as poor network infrastructure, lack of ICT knowledge, weakness of human resources, etc. In order to implement e-learning in Myanmar universities, its implementation should be prepared well because of high time and cost investments. While many developed countries have made significant strides in integrating e-learning platforms into their higher education, developing ones have not yet effectively adopted. Some of them have proven e-learning beneficial for their students, but their majority failed in e-learning adopting. Their primary reason is the lack of e-learning assessment and a number of researches are also required to confirm their challenges so that they can promote more efficient preparation for e-learning. That is why, any universities, which are interested in e-learning, need to know their current situation.

Prior to implementing e-learning, its assessment makes the universities aware of what is required, and whether their students are psychologically and technically prepared. This preparedness is also the degree that a university or an organization is enough to provide e-learning education for individual learners who have no previous e-learning experience, and is called e-learning readiness (Bridges.org., 2005). Moreover, each university has a different level of readiness and therefore, any university must be more careful in determining its e-learning readiness level. Knowing the current readiness level helps the universities so that they can develop the appropriate and operational e-learning policy, which is critical to the success of e-learning implementation.

E-learning cannot succeed based on systems alone. In this case, students are the main stakeholders and perceived beneficiaries from the e-learning system. They might have different perceptions about technology which have a critical influence on their adoption. As both learning and teaching could be conducted via online when e-learning is adopted, the learners' acceptance is necessary and their change in behavior is also essential to express their readiness. Related to this, 
there are a variety of studies in readiness (So \& Swatman, 2010; Robert, 2014; Abdullah \& Toycan, 2018) but the studies about the movements or changes in readiness are scarce.

Changes in readiness leaded to e-learning are also required to be measured from time to time because e-learning is technology-based. Changes in the use and the diffusion of ICT have happened very fast and they represent quantitative and qualitative change. The behaviors of students in using technology might be directly affected and hence, evaluating the changes in e-learning readiness provided by the students is also on-going process until its implementation. In considering the participated universities, this research focuses on two Myanmar technological universities: Yangon Technological University (YTU) and Mandalay Technological University (MTU), because those universities are the best and most popular technological universities, and they are known as Center of Excellence (COE) around the country.

This study aims to examine the changes in e-learning readiness, happened in YTU and MTU. For an innovative shift in the Myanmar learning environment, it addresses the readiness gap of YTU and MTU from 2016 to 2017, by gathering their students' attitudes towards the e-learning, and measures the universities' readiness level from the feedbacks of their students. As the estimations of e-learning preparation are also crucial to reduce the risks, which can be faced for Myanmar universities, this study will be useful. The paper has been organized as follows: research methodology which was used in assessment of technological universities' e-learning readiness, result and discussion, then conclusion and finally, introducing to future researches from the current findings.

\section{Methodology}

This research is conducted as a quantitative study, depending on the students' responds. The questionnaire based on a five-point likert scale, which was previously developed by Paturusi, Chisaki and Usagawa (2014), was applied. The instrument was classified into four dimensions for assessing the students' characteristics, their personal facility and their universities' facilities, their educational environment, and finally, their personal management and their universities' management. The questionnaire consisted of 40 questions and the students, who were studying in different departments and academic year of YTU and MTU, participated to answer those questions. The distribution and collecting data was done, as the paper-based approach, in both August 2016 and January 2017. The population of this research was 648 students in 2016 and 1024 students in 2017. Descriptive statistics was used to summarize each item generated by four dimensions of questionnaires. Moreover, student t-test was applied to assess the differences of students' responds between 2016 and 2017. In comparison readiness, the significant difference was considered at the 0.001 . The level of 'expected e-learning readiness' was measured on the standard mean score, 3.41, which was developed by Aydın and Tasci (2005) and was also adopted in the 
past studies (Soydal et al., 2011; Ouma et al., 2013; Nisperos, 2014; Ünal et al., 2014). The readiness level was bench marked as: "not ready, needs a lot of work to be done" for items between 1 and 2.6, "not ready, but need some work to be done" for items between 2.6 and 3.4, "ready but need a few improvements" for items between 3.4 and 4.2 and "ready to go" for items between 4.2 and 5 .

\section{Result and Discussion}

\subsection{Readiness on Learners' Characteristics}

The "characteristic of learners" dimension intended to check whether Myanmar students, including their learning behaviors and attitudes, are ready for e-education. Table 1 displays that readiness of Myanmar students, related to their characteristics was significantly declining from 2016 to 2017. The present study reveals that the students' computer usage in campus (ST6) caused the highest decline and their usage at home (ST5) was an item with lowest difference. However, they stated their preference in accessing computer outside campus than in campus. It is noteworthy that e-learning without place and time limitations might become one of good learning opportunities for Myanmar students, though a significant downturn in readiness was observed.

\subsection{Readiness on Facilities of Learners and Universities}

The items added in "Facilities" were inserted to confirm whether personal facilities of students cover to access e-learning, and their universities have enough e-learning facilities to support their students. The statistical results in Table 2 indicate the significantly decrease from time to time. It also means that their universities' facilities towards to e-learning have no improvement in 2017. The computer/laptop ownership (ST14) was seen at the lowest difference between two years. The item (ST11) about the number of computers in departments was found as the highest decrease among all the items. One of possible reasons might be that computers in the departments were not able to cover for the increasing numbers of students. The findings recommend that both technological universities should take into account their facilities for e-learning purpose. Because the internet connection, communication devices and equipment located in the universities are elementary requirements to build e-learning tools at campus, to implement e-learning contents by its teachers and to deliver those contents to the students from the campus.

\subsection{Readiness on Learners' Educational Environment}

This items inserted in 'Environment' part were aimed to know if the students' current learning environment, including their friends and teachers, are ready for moving towards e-learning environment. Amazingly, e-learning knowledge is stable and no significant result was found on its item (ST17) from Table 3. Remaining items on this dimension describe their significant down in 2017. In 
Table 1. Statistical analysis on learners' characteristics.

\begin{tabular}{|c|c|c|c|c|c|c|c|c|c|c|c|}
\hline & \multirow[t]{2}{*}{ Statements } & \multicolumn{2}{|r|}{2016} & \multicolumn{2}{|c|}{2017} & \multirow[t]{2}{*}{$\mathrm{t}$} & \multirow[t]{2}{*}{ Sig. } & \multirow{2}{*}{$\begin{array}{c}\text { Mean } \\
\text { Difference }\end{array}$} & \multirow{2}{*}{$\begin{array}{l}\text { Std. Error } \\
\text { Difference }\end{array}$} & \multicolumn{2}{|c|}{$\begin{array}{l}\text { 95\% Confidence } \\
\text { Interval of the } \\
\text { Difference }\end{array}$} \\
\hline & & Mean & $\begin{array}{c}\text { Std. } \\
\text { Deviation }\end{array}$ & Mean & $\begin{array}{c}\text { Std. } \\
\text { Deviation }\end{array}$ & & & & & Lower & Upper \\
\hline ST1 & e-learning Knowledge & 3.81 & 0.71 & 3.62 & 0.83 & 4.87 & 0.000 & 0.19 & 0.04 & 0.12 & 0.27 \\
\hline ST2 & Ready to integrate & 4.15 & 0.70 & 3.85 & 0.83 & 7.79 & 0.000 & 0.31 & 0.04 & 0.23 & 0.38 \\
\hline ST3 & Have enough IT competency & 3.52 & 0.99 & 3.25 & 0.90 & 5.73 & 0.000 & 0.27 & 0.05 & 0.18 & 0.36 \\
\hline ST4 & Prefer e-learning lessons & 3.77 & 0.80 & 3.48 & 0.87 & 6.95 & 0.000 & 0.29 & 0.04 & 0.21 & 0.38 \\
\hline ST5 & Use computer at home & 3.93 & 1.08 & 3.75 & 1.05 & 3.34 & 0.001 & 0.18 & 0.05 & 0.07 & 0.28 \\
\hline ST6 & Use computer at campus & 3.60 & 1.18 & 3.25 & 1.10 & 6.10 & 0.000 & 0.35 & 0.06 & 0.23 & 0.46 \\
\hline ST7 & $\begin{array}{l}\text { Willing to make time for } \\
\text { e-learning }\end{array}$ & 4.17 & 0.70 & 3.88 & 0.79 & 7.76 & 0.000 & 0.29 & 0.04 & 0.22 & 0.37 \\
\hline ST8 & Improve work performance & 4.22 & 0.74 & 3.99 & 0.76 & 5.96 & 0.000 & 0.23 & 0.04 & 0.15 & 0.30 \\
\hline ST9 & $\begin{array}{l}\text { Discipline myself to follow } \\
\text { e-learning courses }\end{array}$ & 3.95 & 0.78 & 3.74 & 0.81 & 5.19 & 0.000 & 0.21 & 0.04 & 0.13 & 0.29 \\
\hline ST10 & Overall, ready for e-learning & 4.03 & 0.81 & 3.75 & 0.82 & 6.66 & 0.000 & 0.27 & 0.04 & 0.19 & 0.35 \\
\hline
\end{tabular}

Table 2. Statistical analysis on facilities of learners and universities.

\begin{tabular}{|c|c|c|c|c|c|c|c|c|c|c|c|}
\hline & \multirow[t]{2}{*}{ Statements } & \multicolumn{2}{|c|}{2016} & \multicolumn{2}{|c|}{2017} & \multirow[t]{2}{*}{$\mathrm{t}$} & \multirow[t]{2}{*}{ Sig. } & \multirow{2}{*}{$\begin{array}{c}\text { Mean } \\
\text { Difference }\end{array}$} & \multirow{2}{*}{$\begin{array}{l}\text { Std. Error } \\
\text { Difference }\end{array}$} & \multicolumn{2}{|c|}{$\begin{array}{l}\text { 95\% Confidence } \\
\text { Interval of the } \\
\text { Difference }\end{array}$} \\
\hline & & Mean & $\begin{array}{c}\text { Std. } \\
\text { Deviation }\end{array}$ & Mean & $\begin{array}{c}\text { Std. } \\
\text { Deviation }\end{array}$ & & & & & Lower & Upper \\
\hline ST11 & $\begin{array}{l}\text { Departments' number of } \\
\text { computers }\end{array}$ & 3.30 & 1.28 & 2.96 & 1.05 & 5.92 & 0.000 & 0.34 & 0.06 & 0.23 & 0.45 \\
\hline ST12 & Computers' quality is good & 3.28 & 1.13 & 3.00 & 0.95 & 5.43 & 0.000 & 0.28 & 0.05 & 0.18 & 0.38 \\
\hline ST13 & University network is fast & 3.05 & 1.21 & 2.73 & 1.11 & 5.60 & 0.000 & 0.32 & 0.06 & 0.21 & 0.44 \\
\hline ST14 & Own personal computer/laptop & 3.94 & 1.26 & 3.83 & 1.16 & 1.79 & 0.074 & 0.11 & 0.06 & -0.01 & 0.23 \\
\hline ST15 & University's IT Infrastructure & 3.38 & 1.07 & 3.15 & 0.90 & 4.91 & 0.000 & 0.24 & 0.05 & 0.14 & 0.33 \\
\hline ST16 & $\begin{array}{l}\text { Overall, IT infrastructure can } \\
\text { support e-Learning }\end{array}$ & 4.06 & 0.79 & 3.80 & 0.84 & 6.22 & 0.000 & 0.26 & 0.04 & 0.18 & 0.34 \\
\hline
\end{tabular}

considering the most declining items, two items (ST24 and ST25) were addressed. It reveals that students' opinion about e-learning efficiencies and their habit of online discussion were lower in 2017 than 2016. But the role of lecturers in e-learning education (ST26) occurred the lowest mean difference between studied periods. The results, which were replied by the students in both 2016 and 2017, indicate that they kept their comprehension and perception on today's education transforming from teacher-based system to student-based system. Their positive attitude is a good opportunity for their universities, in consideration of e-learning adoption.

\subsection{Readiness on Management of Learners and Universities}

The items under "Management" were considered if personal management of students and their university's management are ready towards e-learning. With 
Table 3. Statistical analysis on learners' educational environment.

\begin{tabular}{|c|c|c|c|c|c|c|c|c|c|c|c|}
\hline & \multirow[t]{2}{*}{ Statements } & \multicolumn{2}{|c|}{2016} & \multicolumn{2}{|c|}{2017} & \multirow[t]{2}{*}{$\mathrm{t}$} & \multirow[t]{2}{*}{ Sig. } & \multirow{2}{*}{$\begin{array}{c}\text { Mean } \\
\text { Difference }\end{array}$} & \multirow{2}{*}{$\begin{array}{l}\text { Std. Error } \\
\text { Difference }\end{array}$} & \multicolumn{2}{|c|}{$\begin{array}{l}\text { 95\% Confidence } \\
\text { Interval of the } \\
\text { Difference }\end{array}$} \\
\hline & & Mean & $\begin{array}{c}\text { Std. } \\
\text { Deviation }\end{array}$ & Mean & $\begin{array}{c}\text { Std. } \\
\text { Deviation }\end{array}$ & & & & & Lower & Upper \\
\hline ST17 & $\begin{array}{l}\text { Colleagues' e-learning } \\
\text { knowledge }\end{array}$ & 3.35 & 0.88 & 3.34 & 0.83 & 0.23 & 0.819 & 0.01 & 0.04 & -0.07 & 0.09 \\
\hline ST18 & Colleagues' IT competency & 3.30 & 0.82 & 3.15 & 0.81 & 3.68 & 0.000 & 0.15 & 0.04 & 0.07 & 0.23 \\
\hline ST19 & Colleagues' shared vision & 3.22 & 1.01 & 3.03 & 0.84 & 4.05 & 0.000 & 0.18 & 0.05 & 0.10 & 0.27 \\
\hline ST20 & $\begin{array}{l}\text { University's sharing and } \\
\text { teamwork culture }\end{array}$ & 3.74 & 0.94 & 3.56 & 0.86 & 3.87 & 0.000 & 0.17 & 0.04 & 0.09 & 0.26 \\
\hline ST21 & Lectures' readiness & 3.76 & 0.90 & 3.46 & 0.86 & 6.74 & 0.000 & 0.30 & 0.04 & 0.21 & 0.38 \\
\hline ST22 & Effectiveness of face-to-face & 4.20 & 0.81 & 3.88 & 0.86 & 7.50 & 0.000 & 0.32 & 0.04 & 0.23 & 0.40 \\
\hline ST23 & $\begin{array}{l}\text { e-learning advanced mode in } \\
\text { teaching and learning }\end{array}$ & 4.26 & 0.72 & 4.00 & 0.65 & 7.56 & 0.000 & 0.26 & 0.03 & 0.19 & 0.32 \\
\hline ST24 & $\begin{array}{l}\text { e-learning's efficiency of } \\
\text { disseminating information }\end{array}$ & 4.33 & 0.69 & 3.97 & 0.67 & 10.53 & 0.000 & 0.36 & 0.03 & 0.29 & 0.43 \\
\hline ST25 & Discussion via internet & 3.93 & 0.86 & 3.56 & 0.82 & 8.65 & 0.000 & 0.36 & 0.04 & 0.28 & 0.45 \\
\hline ST26 & $\begin{array}{l}\text { Lecturers' role in information } \\
\text { providing }\end{array}$ & 4.11 & 0.76 & 3.96 & 0.77 & 3.77 & 0.000 & 0.14 & 0.04 & 0.07 & 0.22 \\
\hline ST27 & $\begin{array}{l}\text { Personal touch' importance } \\
\text { in e-learning process }\end{array}$ & 4.20 & 0.73 & 3.90 & 0.71 & 8.26 & 0.000 & 0.30 & 0.04 & 0.23 & 0.37 \\
\hline ST28 & $\begin{array}{l}\text { e-learning's improvement for } \\
\text { teaching and learning }\end{array}$ & 4.15 & 0.71 & 3.87 & 0.71 & 7.90 & 0.000 & 0.28 & 0.04 & 0.21 & 0.35 \\
\hline ST29 & e-learning's opportunities & 4.26 & 0.70 & 3.98 & 0.70 & 8.14 & 0.000 & 0.29 & 0.04 & 0.22 & 0.36 \\
\hline ST30 & $\begin{array}{l}\text { Right time to promote } \\
\text { e-learning }\end{array}$ & 4.32 & 0.75 & 4.03 & 0.80 & 7.45 & 0.000 & 0.29 & 0.04 & 0.21 & 0.37 \\
\hline
\end{tabular}

regard to the statistical results of Table 4, the students' willing to buy computer themselves was weakening in 2017. Because the item (ST32) happened the highest difference. The item (ST39), which described tutorials provided by their university, was the lowest difference during two survey periods. All readiness items exposed their significantly reduction in 2017, if compared their 2016's responds. The findings commend that both universities should consider how to control their educational strategies to integrate technology-based online education. Because the universities' management has an impact on their e-learning adoption. Without their universities' enough preparation, e-learning readiness provided by their students can decline year by year.

\subsection{Readiness Level}

Figure 1 expresses the comparison of e-learning readiness level from 2016 to 2017. The students from two universities have positive attitudes in e-learning but, in 2017, their readiness was significantly declined in all dimensions. The readiness scale directs that facilities and management dimensions are "not ready, needs some work" and should be upgraded from medium into high. But the overall readiness level on their characteristics and their environment were still 
Table 4. Statistical analysis on management of learners and universities.

\begin{tabular}{|c|c|c|c|c|c|c|c|c|c|c|c|}
\hline & \multirow[t]{2}{*}{ Statements } & \multicolumn{2}{|c|}{2016} & \multicolumn{2}{|c|}{2017} & \multirow[t]{2}{*}{$\mathrm{t}$} & \multirow[t]{2}{*}{ Sig. } & \multirow{2}{*}{$\begin{array}{c}\text { Mean } \\
\text { Difference }\end{array}$} & \multirow{2}{*}{$\begin{array}{l}\text { Std. Error } \\
\text { Difference }\end{array}$} & \multicolumn{2}{|c|}{$\begin{array}{l}\text { 95\% Confidence } \\
\text { Interval of the } \\
\text { Difference }\end{array}$} \\
\hline & & Mean & $\begin{array}{c}\text { Std. } \\
\text { Deviation }\end{array}$ & Mean & $\begin{array}{c}\text { Std. } \\
\text { Deviation }\end{array}$ & & & & & Lower & Upper \\
\hline ST31 & University's budget & 3.02 & 1.01 & 2.85 & 0.88 & 3.61 & 0.000 & 0.17 & 0.05 & 0.08 & 0.26 \\
\hline ST33 & Willing to spend extra money & 3.79 & 0.86 & 3.49 & 0.90 & 6.77 & 0.000 & 0.30 & 0.04 & 0.21 & 0.39 \\
\hline ST34 & $\begin{array}{l}\text { IT competency of university IT } \\
\text { manager }\end{array}$ & 3.54 & 0.83 & 3.35 & 0.85 & 4.55 & 0.000 & 0.19 & 0.04 & 0.11 & 0.28 \\
\hline ST35 & $\begin{array}{l}\text { IT competency of university IT } \\
\text { technician(s) }\end{array}$ & 3.66 & 0.82 & 3.40 & 0.82 & 6.39 & 0.000 & 0.26 & 0.04 & 0.18 & 0.34 \\
\hline ST36 & $\begin{array}{l}\text { Number of university IT } \\
\text { technicians }\end{array}$ & 3.44 & 0.89 & 3.23 & 0.82 & 5.08 & 0.000 & 0.22 & 0.04 & 0.13 & 0.30 \\
\hline ST37 & $\begin{array}{l}\text { Can overcome technical } \\
\text { problem }\end{array}$ & 3.00 & 0.97 & 2.85 & 0.91 & 3.37 & 0.001 & 0.16 & 0.05 & 0.07 & 0.25 \\
\hline ST38 & $\begin{array}{l}\text { University provides enough } \\
\text { training }\end{array}$ & 3.15 & 0.97 & 3.01 & 0.86 & 3.10 & 0.002 & 0.14 & 0.05 & 0.05 & 0.23 \\
\hline ST39 & $\begin{array}{l}\text { University provides enough } \\
\text { tutorial }\end{array}$ & 3.05 & 1.01 & 2.84 & 0.89 & 4.52 & 0.000 & 0.21 & 0.05 & 0.12 & 0.30 \\
\hline ST40 & $\begin{array}{l}\text { Overall, university technical } \\
\text { support is adequate }\end{array}$ & 3.28 & 1.06 & 2.97 & 0.88 & 6.44 & 0.000 & 0.31 & 0.05 & 0.21 & 0.40 \\
\hline
\end{tabular}

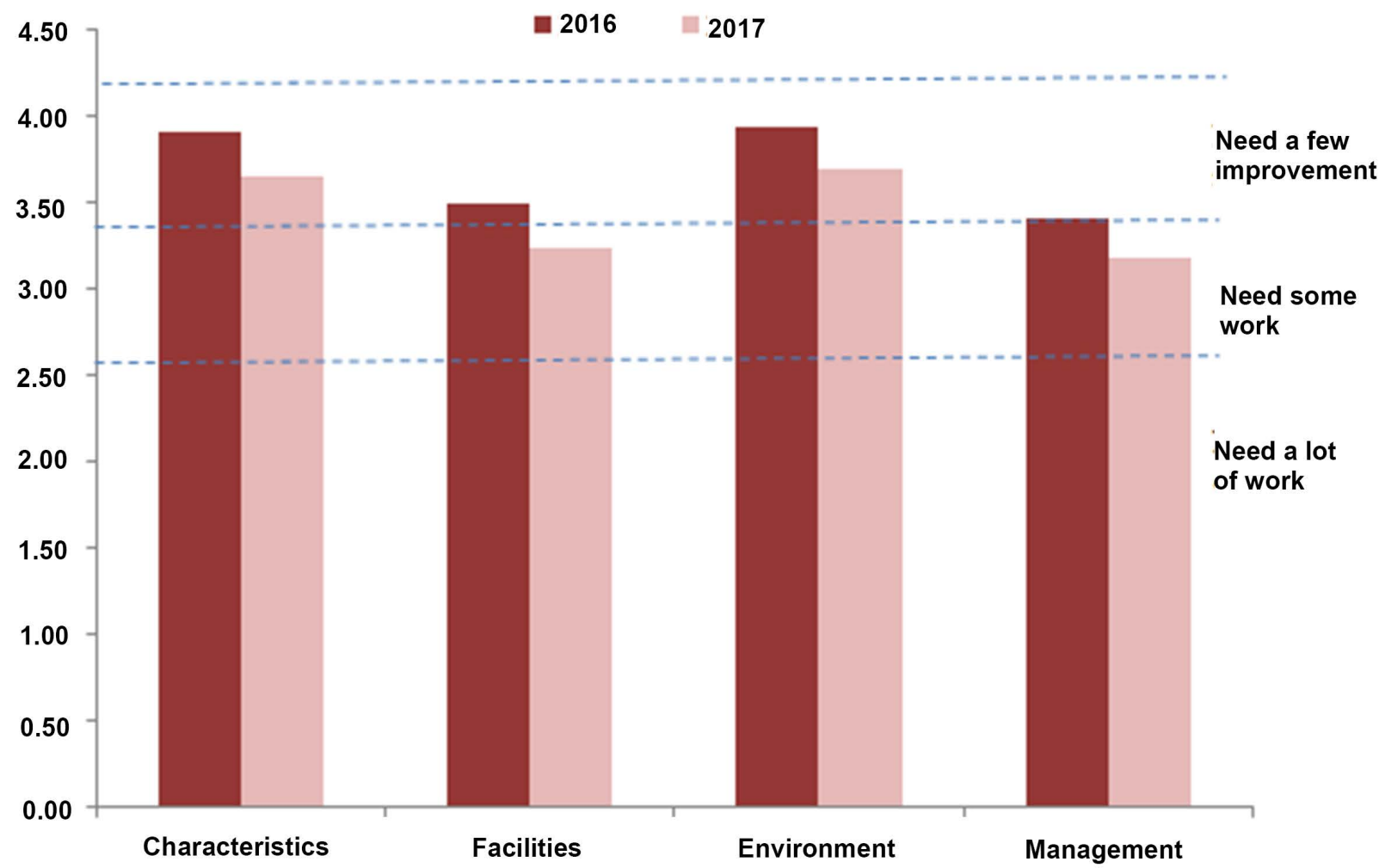

Figure 1. Readiness level of four dimensions. 


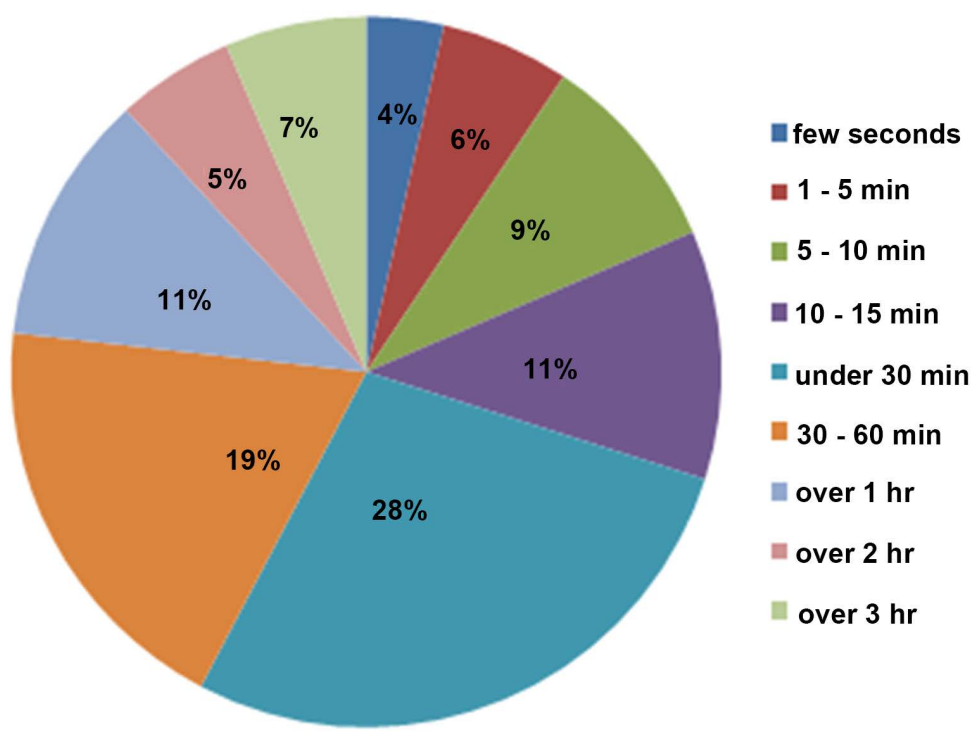

Figure 2. Blackout duration.

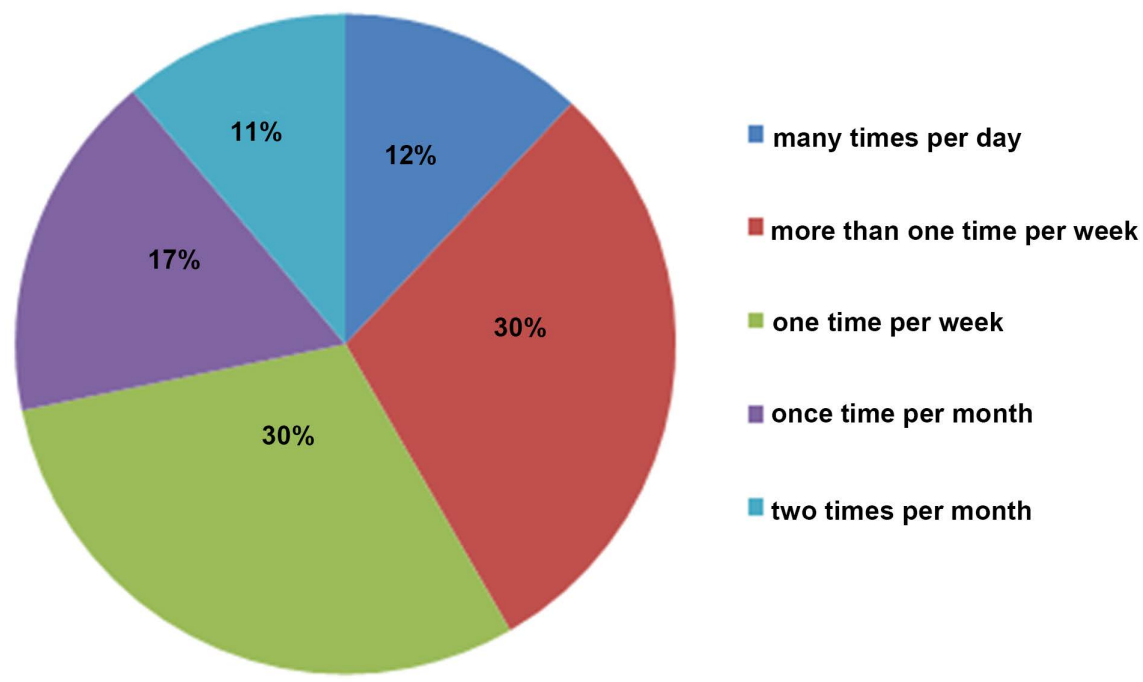

Figure 3. Blackout times.

above the standard score. It is noted that both universities are able for e-learning but should emphasize on some preparation towards e-learning education.

\subsection{Blackout Challenge for Universities}

In the survey period of 2017, the study on electricity blackout was also done. The students' responds in Figure 2 direct the blackout problem in campus. They replied that the blackout time in campus used to be long less than 30 minutes. Figure 3 displays the numbers of blackout times, which often happened in their campus. As the highest percentage, the students responded their universities have at least one blackout time per week. Results found in Figure 2 and Figure 3 mention that both universities are facing with unstable electricity problem, even though they are the Myanmar's COE technological universities. It also reveals 
that unstable electricity is one of major barriers for Myanmar universities to start e-learning. That's why, to implement e-learning tools and run them without time limitation, Myanmar universities have to solve their infrastructure issues.

\section{Conclusion}

This study examines the changes in e-learning readiness from time to time. The readiness is unstable although the participated students displayed their positive attitudes towards e-learning, in both survey times. Depending on the readiness level, the findings confirm that the facilities and managements of Myanmar universities significantly decreased in 2017 than 2016. In addition, the results recommend both $\mathrm{COE}$ technological universities to focus on how to fulfill necessary facilities and how to drive their universities' strategies toward e-readiness. In this study, the students' computer usage at campus, computer in departments, opinion about e-learning's efficiency, discussion via online and their willing to buy computer were examined as the readiness items caused the highest declines in 2017. Moreover, the study describes the problem of power outage which Myanmar students are often facing in campus. It alerts that Myanmar students' e-learning readiness might be down from time to time, if their universities have no effort to upgrade their facilities and management. To confirm the students' readiness changes and know their up-to-date requirements for e-learning, future studies, including their communication devices and behaviors of internet access, should be carried out until e-learning can be implemented.

\section{Acknowledgements}

Part of this work was supported by Grant-in-Aid for Scientific Research 25280124 and $15 \mathrm{H} 02795$. The authors would like to thank all the students from various departments of YTU and MTU for their active cooperation during this research.

\section{References}

Abdullah, M. S., \& Toycan, M. (2018). Analysis of the Factors for the Successful E-Learning Services Adoption from Education Providers' and Students' Perspectives: A Case Study of Private Universities in Northern Iraq. Eurasia Journal of Mathematics, Science and Technology Education, 14, 1097-1109.

Aung, T. N., \& Khaing, S. S. (2016). Challenges of Implementing E-Learning in Developing Countries: A Review. In Genetic and Evolutionary Computing, Advances in Intelligent Systems and Computing (pp. 405-411). Switzerland: Springer International Publishing. https://doi.org/10.1007/978-3-319-23207-2_41

Aydin, C. H., \& Tasci, D. (2005). Measuring Readiness for E-Learning: Reflections from an Emerging Country. Educational Technology \& Society, 8, 244-257.

Bridges.org. (2005) E-Ready for What? E-Readiness in Developing Countries: Current Status and Prospects toward the Millennium Development Goals. http://www.infodev.org/infodev-files/resource/InfodevDocuments_3.pdf

Nisperos, L. S. (2014). Assessing the E-Learning Readiness of Selected Sudanese Universi- 
ties. Asian Journal of Management Sciences \& Education, 3, No. 4.

Ouma, G. O., Awuor, F. M., \& Kyambo, B. (2013). E-Learning Readiness in Public Secondary Schools in Kenya. European Journal of Open, Distance and E-Learning, 16, No. 2.

Paturusi, S., Chisaki, Y., \& Usagawa, T. (2014). Assessing Lecturers and Student's Readiness for E-Learning: A Preliminary Study at National University in North Sulawesi Indonesia. In Annual International Conference on Education \& E-Learning (pp. 132-137). Bangkok.

Po, P. T. W. (2015). An Overview of Higher Education Reform in Myanmar. In International Conference on Burma/Myanmar Studies, Burma/Myanmar in Transition: Connectivity, Changes and Challenges (pp. 1-16). Chiang Mai: University Academic Service Centre (UNISERV), Chiang Mai University.

http://www.burmalibrary.org/docs21/Education/Popo-Thaung-Win-2015-An_Overvie w_of_Higher_Education_Reform_in_Myanmar-en.pdf

So, T., \& Swatman, P. (2010). Assessing E-Learning Readiness of Teachers and Schools in Hong Kong. In Proceedings of Global Learn Asia Pacific 2010 Global Conference on Learning and Technology (pp. 4051-4059). Penang, Malaysia.

http://www.learntechlib.org/noaccess/34497/

Soydal, I., Alır, G., \& Ünal, Y. (2011). Are Turkish Universities Ready for E-learning: A Case of Hacettepe University Faculty of Letters. Information Services \& Use, 31, 281-291. https://doi.org/10.3233/ISU-2012-0659

Tint, H. (2012). Perspectives of Open and Distance Learning in Myanmar. Yangon University of Distance Education. http://www.tonybates.ca/wp-content/uploads/ODL-in-Myanmar.pdf

Ünal, Y. Alır, G., \& Soydal, I. (2014). Students Readiness for E-Learning: An Assessment on Hacettepe University Department of Information Management. In J.N. Gathegi et al. (Eds.), IMCW (Vol. 423). Limerick: CCIS, 137-147. https://doi.org/10.1007/978-3-662-44412-2_13

Yin, H. Z. (2014). Enlarging the Opportunities of Accessing Quality Higher Education in Myanmar: The COE Project. M.S. Dissertation. Porto: University of Porto. https://repositorio-aberto.up.pt/bitstream/10216/74299/2/32241.pdf

Robert, A. O. (2014). Assessing E-Learning Readiness at the Kenya Technical Teachers College. Journal of Learning for Development-JL4D, 1, No. 3. 